\title{
ASSESSMENT OF BIOACTIVE METABOLITES FROM THE ROOT ENDOPHYTE ISOLATED FROM CASUARINA JUNGHUHNIANA MIQ.
}

\author{
PRIYOM BOSE, UMA GOWRIE S*
}

Department of Plant Biology and Plant Biotechnology, Ethiraj College for Women, Chennai, Tamil Nadu. Email: umasezhian@gmail.com Received: 28 November 2016, Revised and Accepted: 09 December 2016

\begin{abstract}
Objective: Casuarina junghuhniana Miq. is a well-known multipurpose tree belonging to family Casuarinaceae. This tree has the ability to sustain in different edaphic and extreme environmental conditions. The root extract of this tree is a rich source of potential secondary metabolites. Therefore, the main objective of this study is to isolate fungal root endophyte from this tree and to determine its bioactive compound which can be utilized in agriculture and pharmaceutical industries.
\end{abstract}

Methods: C. junghuhniana Miq. root samples were collected from the State Forestry Research Institute, Neyveli (Vridhachalam Research Range, Cuddalore District). Isolation of fungal endophyte was carried out using potato dextrose agar medium. The qualitative and quantitative phytochemicals screening and enzyme assays were carried out using standard procedures. Antimicrobial assay was tested against different pathogens using well diffusion method. Further, the phytochemicals in the root extract were evaluated using Fourier transform infrared (FTIR), high performance liquid chromatography (HPLC), and gas chromatography-mass spectrometry (GC-MS) studies.

Result: Among the isolated endophytes, the dominant isolate (CJN5) was identified as Aspergillus sp. which showed positive result in the production of industrially important enzymes, namely, cellulase, lipase, and amylase. The qualitative screening revealed the presence of various phytoconstituents. Total phenolic content of culture filtrate extract (CFE) (208.20 $\pm 2 \mathrm{mg} / \mathrm{g}$ ) was found higher than culture mycelium extract (CME) (165.5 $\pm 3 \mathrm{mg} / \mathrm{g}$ ). The total flavonoid content of CFE $(25.95 \pm 2 \mathrm{mg} / \mathrm{g})$ was also found higher than CME (3.59 $2 \mathrm{mg} / \mathrm{g})$ using respective standards. Antimicrobial activity showed maximum zone of inhibition against Pseudomonas aeruginosa (bacterial pathogen) (24 \pm 0.1 mm) and Fusarium oxysporum (fungal phytopathogen) (34 $\pm 0.2 \mathrm{~mm}$ ). FTIR analysis showed the presence of varied functional groups. HPLC study revealed the presence of gallic acid and salicylic acid. Several peaks were obtained in GC-MS analysis which indicates the presence of different secondary metabolites.

Conclusion: Aspergillus sp, isolated from the root of $C$. junghuhniana Miq. is a promising source of bioactive compounds which can be utilized in agriculture and pharmaceutical industries.

Keywords: Endophyte, Casuarina junghuhniana, Phytochemical, Antimicrobial, High performance liquid chromatography, Gas chromatography-mass spectrometry.

(C) 2017 The Authors. Published by Innovare Academic Sciences Pvt Ltd. This is an open access article under the CC BY license (http://creativecommons. org/licenses/by/4. 0/) DOI: http://dx.doi.org/10.22159/ajpcr.2017.v10i4.16382

\section{INTRODUCTION}

Emergence of new diseases due to rapid resistance of the existing drugs against harmful pathogenic microorganisms has drawn an indisputable need for biologically active secondary metabolites [1]. An intensive search for effective antimicrobial agents can be pursued by exploring new niches and habitats [2]. In recent past, endophytes represent a diverse group of microbes which inhabits in special and unusual environmental conditions, making them a potential source for new drugs for medicinal and agricultural use [3].

Endophytes are microorganisms that reside within a healthy living plant tissue without causing any substantive negative effect to the host plant $[4,5]$. Endophytes have symbiotic relationship with their host [6]. Several studies revealed that the endophytic fungus is able to produce bioactive compounds similar to that of its host plant [7]. As natural selection favors the evolution of potential endophytic microbes, endophytes are producers of various bioactive secondary metabolites that protects the host plants from pest, pathogenic organisms, herbivores and insect attacks $[8,9]$. In comparison to plants, microbial source of biologically active compounds are easier and more economical in case of large-scale production [10]. Therefore, endophytic microorganisms are promising source of novel bioactive compounds for pharmaceutical, medicinal, and agricultural applications $[11,12]$.

Survey of many tree species over three decades showed that colonization of endophytic fungi is ubiquitous. The number of endophytic microorganisms residing within the host depends on biotic, abiotic, and various environmental factors [13]. Phomopsis sp., a fungal endophyte, isolated from various tree species such as Pinus sp., Acer sp., and Plumeria sp. are reported to be a rich source of secondary metabolites due to which it exhibits strong antimicrobial activity thereby it protects the host plant from disease causing pathogen [14].

Casuarina junghuhniana Miq. is an exotic, fast growing actinorhizal tree which belongs to the family Casuarinaceae. It is a drought tolerant plant which can withstand varied soil type and wide range of $\mathrm{pH}$. It is known to be rich in various phytoconstituents such as alkaloids, carbohydrates, triterpenoids, phenols, flavonoids, tannins, and steroids. This tree crop provides land reclamation, dune stabilization, vegetative shelter bed, bioshield and can improve soil fertility in tropical and subtropical regions [15]. In recent past, it is gaining its value as an important agroforestry species and also used in intercropping with many shortterm agricultural crops, vegetable and also with medicinal plants [16]. This tree crop is extensively used for pulping in paper industries as that of Casuarina equisetifolia [17].

Hence, the objective of this study is to isolate endophytic fungi from the root of $C$. junghuhniana Miq. and to screen the qualitative and quantitative phytochemical constituents and to study their antimicrobial activity against phytopathogens. Further, the production of extra cellular enzyme by the potential isolate was assayed. Fourier transform infrared (FTIR), high performance liquid chromatography 
(HPLC), and gas chromatography-mass spectrometry (GC-MS) analysis were carried out to characterize the presence of bioactive compounds.

\section{METHODS}

\section{Source of endophytic fungi}

The plant root material of the C. junghuhniana Miq. was collected from the State Forest Research Institute, Neyveli (Vridhachalam Research Range, Cuddalore District), Tamil Nadu. The root samples of the plant were collected in random manner at the plantation site, kept in a sterile polythene bags, and then stored at $4^{\circ} \mathrm{C}$ until further isolation process was conducted. Identification (authentication) of the plant samples were confirmed at Botanical Survey of India (BSI) Coimbatore, Tamil Nadu (Confirmation I.D No: BSI/SRC/5/23/2015/Tech/2154).

\section{Isolation of endophytic fungi}

The root samples were washed in running tap water to remove soil particles and adhered debris. These were rewashed in distilled water. The tissue segments were sterilized using the modified method of [18] Fisher et al. (1993) and were individually inoculated in Petri plates containing potato dextrose agar (PDA) medium supplemented with streptomycin $(100 \mathrm{mg} / \mathrm{L})$. These Petri plates were incubated at $37^{\circ} \mathrm{C}$ (room temperature) for 3 days. After attaining visible growth, the fungal colonies were sub cultured in PDA plates and stored at $4^{\circ} \mathrm{C}$. The colonization frequency (CF\%) and endophytic infection rate (EIR\%) of each endophytic fungi were calculated and determined using the following formula [19]:

$\mathrm{CF} \%=\frac{\text { Number of segments colonized by an endophyte }}{\text { Total number of segments }} \times 100$

EIR $\%=\frac{\text { Number of infected segments }}{\text { Total number of segments screened }} \times 100$

\section{Identification of endophytic fungi}

The identification of the fungal endophyte was done on the basis of its colony morphology, pigmentation, spores at the hyphal tip using standard manual [20].

\section{Fermentation and extraction}

Two or three pieces of agar plugs were cut out from the culture plate and were inoculated in a $250 \mathrm{ml}$ Erlenmeyer flask containing $150 \mathrm{ml}$ potato dextrose broth for 21 days at $30^{\circ} \mathrm{C}$. The fungal broth culture was filtered to remove the mycelium. The filtrate was extracted with ethyl acetate solvent (1:1) three times. Fungal secondary metabolites in the mycelial mat were extracted using solvent extraction method with ethyl acetate as the organic solvent (14). The organic phase was evaporated to dryness and stored at $4^{\circ} \mathrm{C}$ for future usage. The culture filtrate extract (CFE) and culture mycelium extract (CME) were dissolved in dimethyl sulfoxide to obtain different concentration.

\section{Phytochemical analysis}

The ethyl acetate extract (CFE and CME) of the endophytic fungi was screened for the presence of the secondary metabolites such as alkaloids, cardiac glycosides, carbohydrate, protein and amino acids, phenols, flavonoids, tannins, terpenoids, phlobatannin, anthraquinone, gums, and mucilage by standard procedures [21].

\section{Determination of total phenolic content (TPC)}

The TPC in CFE and CME were determined using Folin-Ciocalteu's colorimetric method. $0.2 \mathrm{ml}$ of sample were oxidized with $0.5 \mathrm{~N}$ FolinCiocalteu's reagents for 4 minutes at room temperature. Then, the reaction was neutralized with saturated sodium carbonate $(75 \mathrm{~g} / \mathrm{l})$. After $2 \mathrm{hrs}$ of incubation at room temperature in dark, the absorbance of the resulting blue color was measured at $760 \mathrm{~nm}$ in UV-Vis spectrophotometer (UV 1650 PC Shimadzu). The concentration of total phenol was determined on the basis of calibration curve using gallic acid (GA). The content was expressed in milligram of GA equivalents (GAEs) per gram of extract studied [22].

\section{Determination of total flavonoid content}

Total flavonoid content in CFE and CME was determined using colorimetric method [23]. Extract samples (0.25 ml) at concentration of $1 \mathrm{mg}$ extract $\mathrm{ml}^{-1}$ were diluted with distilled water $(1.25 \mathrm{ml}) .0 .75 \mathrm{ml}$ of $5 \%$ sodium nitrate solution was added and the sample was incubated for $6 \mathrm{hrs}$ at room temperature. $0.15 \mathrm{ml}$ of $10 \%$ aluminum chloride was added and the resulting mixture was incubated for 5 minutes. Finally, $0.50 \mathrm{ml}$ of sodium hydroxide (1M) was added and was made up to $2.5 \mathrm{ml}$ with distilled water, incubated for 30 minutes at $25^{\circ} \mathrm{C}$. Absorbance was measured at $510 \mathrm{~nm}$ in UV-Vis spectrophotometer. The concentration of total flavonoid was determined on the basis of the calibration curve using quercetin as standard. The content was expressed in milligram of quercetin equivalents per gram of the extract studied.

\section{Enzyme assay}

The pure culture of the isolate was screened for the production of the extracellular enzyme (amylase, cellulase, lipase, laccase, and protease). It was assayed by the digestion of the dissolved or suspended substrate amended in the agar plate. After inoculation of the isolates, incubation of 3-4 days at $37^{\circ} \mathrm{C}$ produces a clear zone around the fungal colony which determines the production of extracellular enzymes [24].

\section{Antimicrobial activity}

Two different concentrations of CFE and CME (50 and $100 \mu \mathrm{g}$ ) were individually assayed against test phytopathogens. Bacteria such as Bacillus subtilis and Pseudomonas aeruginosa were maintained in nutrient agar (NA) slants and fungi such as Fusarium solani, Fusarium oxysporum, Macrophomina phaseolina, Alternaria alternata, Curvularia lunata, and Rhizoctonia solani were maintained in PDA slants for further analysis. This assay was carried out using well diffusion method following standard method [25]. PDA and NA medium were used for the assay. Gentamycin $(100 \mu \mathrm{g})$ and carbendazim $(100 \mu \mathrm{g})$ were used as positive control whereas ethyl acetate solvent was used as negative control. Triplicates were maintained for all the samples. The plates were incubated for 24 hrs at $37^{\circ} \mathrm{C}$ for bacteria and $48-72 \mathrm{hrs}$ at room temperature for fungal pathogens. Zone of inhibition was observed and measured.

\section{FTIR spectroscopy analysis}

The crude fungal extract of CFE was subjected to FTIR analysis to determine the different functional groups present in the sample. FTIR spectral system (Shimadzu, IR Affinity 1, Japan), equipped with a DLATGS detector with a mirror speed of $2.8 \mathrm{~mm} /$ seconds scan range: From 400 to $4000 / \mathrm{cm}$ with a resolution of $4 / \mathrm{cm}$ was used for this analysis. The dried samples were finely grounded using potassium bromide $(\mathrm{KBr})$ in 1:10 ratio. The IR pellet was recorded in the region $4000-400 / \mathrm{cm}$ and the functional group of the bioactive substance was recorded, the resulting spectrum was characteristic of the organic molecules present in CFE.

\section{HPLC analysis}

\section{Sample preparation}

The ethyl acetate extract of the sample was filtered through Whatman No. 1 filter paper and the filtrate was evaporated to dryness. Dried sample was resuspended in $1 \mathrm{ml}$ HPLC graded methanol by vortexing. The samples were further filtered through $0.45 \mathrm{~mm}$ membrane (Millipore) and were stored at $4^{\circ} \mathrm{C}$ for HPLC analysis. Salicylic acid (SA) and GA standards were prepared using HPLC graded methanol and used for analysis.

\section{Chromatographic conditions}

HPLC system was equipped with SHIMADZU (Kyoto, Japan). LC 20 AD pump, SPD 20 A- UV detector (SHIMADZU) with wavelength set at $280 \mathrm{~nm}$, LC solution software recorder (Integrator, Spectra-physics, Mountain view, CA). Room temperature was maintained. Reverse phase chromatographic analysis was carried out in isocratic condition using C-18 reverse phase column (Phenomenex 250) (Merck, Darmstadt, Germany). $20 \mu \mathrm{l}$ of the prepared sample solution was injected by autosampler. Mobile phase used for separation was methanol:HPLC graded distilled water:1\% acetic acid (80:20:1), $1 \mathrm{ml} /$ minute flow rate, low pressure. 
Phenolic compounds present in the sample was detected on the basis of comparison with the retention time (Rt) of the sample with that of the Rt of the individual standards at similar chromatographic conditions.

\section{GC-MS analysis}

The fungal extract was subjected to GC-MS analysis to identify the bioactive compounds. GC-MS analysis was performed at the SAIF, IIT-Madras, Chennai, Tamil Nadu. The sample was subjected to GC and MS JEOL GC mate equipped with secondary electron multiplier. JEOL GCMATE II GC-MS (Agilent Technologies 6890N Network GC system for gas chromatography). The column (HP5) was fused silica $50 \mathrm{~m} \times 0.25 \mathrm{~mm}$ I.D. The experimental conditions were 20 minutes at $100^{\circ} \mathrm{C}$, column temperature: $235^{\circ} \mathrm{C}$ for $3 \mathrm{~min}$; injector temperature: $240^{\circ} \mathrm{C}$; carrier gas: Helium; split ratio: 5:4.1 1 l of the sample was evaporated in a split less injector at $300^{\circ} \mathrm{C}$ and the run time was 30 minutes. The active phytochemical components were identified by gas chromatography coupled with mass spectrometry. The spectrum of GC-MS was analyzed using the database of the National Institute Standard and Technology (NIST) having more than 62,000 patterns.

\section{RESULTS AND DISCUSSION}

Endophytes are microorganisms which reside within a healthy plant, giving it protection against pest and pathogens. Endophytes have proven to be a promising source of the novel bioactive compounds with a wide range of biological activities. The role of endophytes as biocatalyst in the biotransformation process holds great importance in pharmaceutical industry [26]. In this study, total of twelve endophytic fungus has been isolated (41\% sporulating and 59\% of nonsporulating) from the root of C. junghuhniana Miq. Among which, Aspergillus sp. (Fig. 1a and b) was identified to be the most dominant endophyte with a higher frequency of occurrence (31\%) and was thus selected for further studies.

\section{Enzyme assay}

Endophytic fungi are potential enzyme producers. In this study, endophytic fungus Aspergillus sp. was able to produce amylase, lipase, and cellulase enzyme (Fig. 2a-c), however, it was unable to produce laccase and protease enzyme. Endophytes secrete extracellular such as protease, amylase, lipase, cellulase, xylanase that can degrade plant surfaces and cell walls to promote intercellular or intracellular colonization [26]. Production of cellulase enzyme from fungal endophyte proved to be an effective alternative for large-scale, low cost enzyme production [27]. Lipase is extensively used in medicine and food industries [28,29]. Even though, amylase can be obtained from
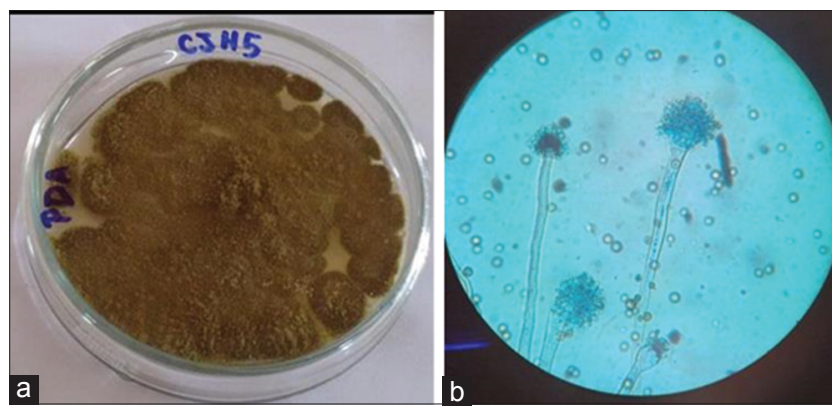

Fig. 1: (a) Colony morphology of CJN5. (b) Microscopic structure of CJN5

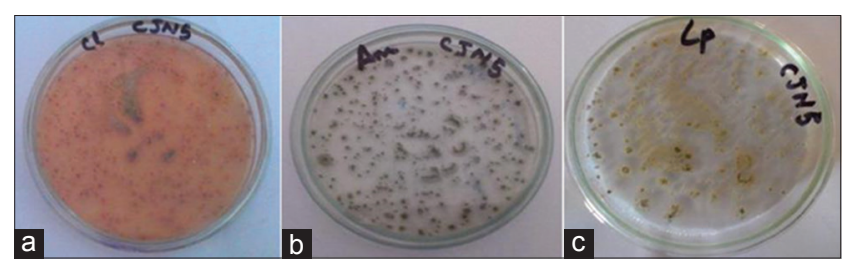

Fig. 2: (a) Cellulase (b) Amylase (c) lipase produced by Aspergillus sp. various sources such as plant, animal, and microorganisms, industrial demands are usually met by microbial sources [30,31]. Microbial sources are generally preferred over plant and animal sources because they are more economical to produce as well as more stable [9].

\section{Phytochemical analysis}

Qualitative phytochemical analysis inferred that alkaloid, cardiac glycoside, carbohydrate, terpenoid, phenol, flavonoid, protein, and amino acid were present in both CFE and CME. Tannin was present in CME whereas anthraquinone was found in CFE. Phlobatannin, gums, and mucilage were absent in both CFE and CME. In past decades, many important secondary metabolites were obtained from endophytic fungi. Biologically active secondary metabolites such as alkaloids, tannin, phenol, flavonoid, cardiac glycosides, carbohydrate, anthraquinone, and terpenoids are used in pharmaceutical and agricultural industries [32,33]. Phytoconstituents acts as an indicator which can be exploited as precursors in the development of synthetic drugs [34,35].

\section{Total phenol and flavonoid content}

The TPC of CFE and CME was determined by Folin-Ciocalteu's method were reported as GAE (standard curve equation $\mathrm{Y}=0.027 \mathrm{X}+0.176$, $\left.\mathrm{R}^{2}=0.994\right)$. TPC of CFE $(208.20 \pm 2 \mathrm{mg} / \mathrm{g})$ was found higher than CME $(165.5 \pm 3 \mathrm{mg} / \mathrm{g})$.

The total flavonoid content of CFE and CME was determined by aluminum chloride method were reported as quercetin equivalent (standard curve equation, $\left.\mathrm{Y}=0.009 \mathrm{X}+0.136, \mathrm{R}^{2}=0.997\right)$. The total flavonoid content of CFE $(25.95 \pm 2 \mathrm{mg} / \mathrm{g})$ was found higher than CME $(3.59 \pm 2 \mathrm{mg} / \mathrm{g})$.

Phenols and flavonoid compounds are known to possess various bioactivities. Phenols and polyphenols are largest groups of secondary metabolite having antimicrobial property [36]. The number of phenolic groups may attribute to their relative toxicity to microorganism because of increase in hydroxylation causing greater toxicity [37]. The difference in the antibacterial activity can be attributed to the class of flavonoids (flavones, flavonols, flavan-3-ols, isoflavones, flavanones, and anthocyanidins) and/ or their chemical structure, specifically in regards to the position and number of methoxy and phenolic group within their structure [38-40].

\section{Antimicrobial activity}

Antibacterial activity of CFE and CME against B. subtilis and P. aeruginosa was studied. CFE showed maximum zone of inhibition against $P$. aeruginosa $(24 \pm 0.1 \mathrm{~mm})$ at $100 \mu \mathrm{g}$ concentration (Fig. 3a and c) followed by $B$. subtilis ( $21 \pm 0.3 \mathrm{~mm}$ ). In this case, both the test bacterial pathogen were showing higher susceptibility when compared with the control. However, for $50 \mu \mathrm{g}$ concentration B. subtilis $(19 \pm 0.3 \mathrm{~mm})$ showed higher inhibition zone than $P$. aeruginosa $(16 \pm 0.3 \mathrm{~mm})$. CME was found to be less efficient in comparison to CFE. Similar to CFE, CME also showed maximum zone of inhibition against $P$. aeruginosa at $100 \mu \mathrm{g}$ concentration $(18 \pm 0.1 \mathrm{~mm})$ followed by B. subtilis $(10 \pm 0.2 \mathrm{~mm})$. At $50 \mu$ g concentration $P$. aeruginosa $(15 \pm 0.3 \mathrm{~mm})$ showed higher zone of inhibition than $B$. subtilis $(3 \pm 0.3 \mathrm{~mm})$.

Similarly, antifungal activity was studied against phytopathogens, namely, F. solani, F. oxysporum, R. solani, A. alternata, C. lunata, and M. phaseolina. CFE showed maximum zone of inhibition at $100 \mu \mathrm{g}$ concentration against F. oxysporum ( $34 \pm 0.2 \mathrm{~mm}$ ) (Fig. $3 \mathrm{~b}$ and c) followed by $R$. solani $(27 \pm 0.4 \mathrm{~mm}), M$. phaseolina $(26 \pm 0.5 \mathrm{~mm}), F$. solani $(25 \pm 0.4 \mathrm{~mm})$, C. lunata $(12 \pm 0.3 \mathrm{~mm})$, and A. alternata $(10 \pm 0.3 \mathrm{~mm})$. At $50 \mu \mathrm{g}$ concentration, maximum zone of inhibition was found against $R$. solani $(26 \pm 0.4 \mathrm{~mm})$ which is higher than control followed by $F$. oxysporum $(8 \pm 0.3 \mathrm{~mm})$, A. alternata $(7 \pm 0.3 \mathrm{~mm})$, and C. lunata $(6 \pm 0.1 \mathrm{~mm})$. No zone of inhibition was found against $F$. solani and M. phaseolina. CME showed maximum zone of inhibition at $100 \mu \mathrm{g}$ concentration against $R$. solani $(28 \pm 0.2 \mathrm{~mm})$ followed by $F$. solani $(24 \pm 0.3 \mathrm{~mm}), F$ oxysporum $(22 \pm 0.2 \mathrm{~mm})$, M. phaseolina $(9 \pm 0.5 \mathrm{~mm})$, A. alternata $(7 \pm 0.2 \mathrm{~mm})$, and $C$. lunata $(5 \pm 0.4 \mathrm{~mm})$. At $50 \mu \mathrm{g}$ concentration, maximum zone of inhibition was found against $R$. solani $(16 \pm 0.4 \mathrm{~mm})$ followed by $F$. solani $(7 \pm 0.5 \mathrm{~mm})$, A. alternata $(4 \pm 0.3 \mathrm{~mm})$, and C. lunata $(2 \pm 0.1 \mathrm{~mm})$. 
Several researchers have reported various secondary metabolites such as phenol, flavonoid, alkaloid, and terpenoids produced by fungal endophytes have effective antimicrobial activity. Antimicrobial metabolites obtained by fermentation of fungal endophytes have greater advantage including no destruction of the resources, largescale commercial production, and reliable quality [41]. In this study, it was found that both CFE and CME contain high phenolic concentration which might attribute to its antimicrobial activity. Phenolic compound is involved in different mode of action like inhibition of synthesis of nucleic acid, destabilization and permeabilization of cytoplasmic membrane, resulting to its antimicrobial activities [42].

\section{FT-IR analysis}

FT IR analysis of the endophytic isolate Aspergillus sp. reveals the presence of different functional groups in the organic fraction. Major peaks in the FT IR analysis (Fig. 4) showed the presence of alkane $(2925.17 / \mathrm{cm})$, OH- group $(3433.44 / \mathrm{cm})$, aromatic amines $(2858.63 / \mathrm{cm})$, aliphatic compound $(1459.1 / \mathrm{cm}), \quad \mathrm{C}=0$ alkene $(1611.59 / \mathrm{cm})$, alkene $(1727.33 / \mathrm{cm})$, primary aliphatic amines $(1031.00 / \mathrm{cm})$. Existence of different potential phytochemicals in the fungal endophyte extract may be due to the presence of various functional groups. The presence of different functional groups reflects the complex structure secondary metabolite [43].

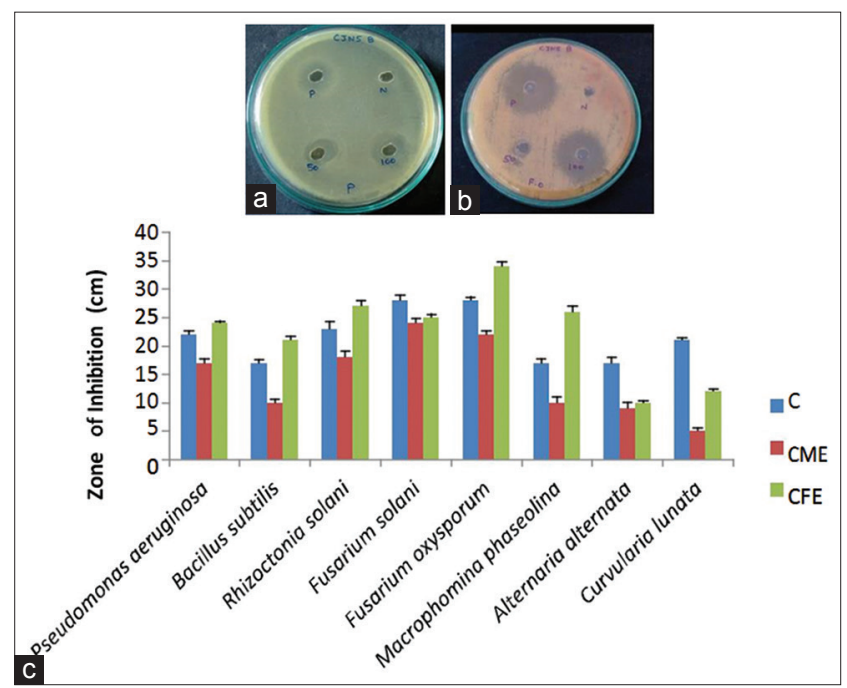

Fig. 3: (a) Aspergillus sp. showing maximum zone of inhibition against Pseudomonas sp. (b) Aspergillus sp. showing maximum zone of inhibition against Fusarium oxysporum. (c) Antimicrobial activity of culture mycelium extract and culture filtrate extract at $100 \mu \mathrm{g}$ concentration

\section{HPLC analysis}

HPLC analysis of endophytic Aspergillus sp. revealed 4 sharp peaks at different Rt. Among these, two peaks were identified as GA (Rt 2.9 minutes) and SA (Rt 3.8 minutes) (Fig. 5a-c). The presence of these compounds was confirmed on comparing its Rt with that of its standard under similar chromatographic conditions.

In plants, resistance toward pathogenic infection is achieved through protective physical barriers or various antimicrobial agents. It is reported that SA is one of the key signaling molecule in multiple signaling transduction pathway for disease resistance in Arabidopsis sp [44]. Endophytic bacteria Achromobacter sp. produces SA and inhibits growth of pathogenic fungi [45]. GA involves in irreversible changes in membrane properties in respect to hydrophobicity changes, formation of pore in the cell membrane or local ruptures that causes leakage of the essential cellular constituents. [42]. Fungal endophyte Phomopsis sp. is reported to produce GA which possess antimicrobial property [46].

\section{GC-MS analysis}

Several peaks were obtained in GC-MS analysis of endophytic fungus Aspergillus sp. indicating the presence of different secondary metabolites (Fig. 6). These bioactive compounds were identified using NIST database on comparison with actual mass spectral obtained. The chromatogram determines the presence of 4,5,7-Trihydroxy isoflavone (80.2\%), Estra-1,3,5(10)-trien 17 a-ol (5.4\%), Phytol (77.8\%), 4H-1Benzopyran 4-one,2-(3,4-dimethoxy phenyl-7-hydroxy (89.9\%), (E)-9Octadecenoic acid ethyl ester (6.7\%), Eicosanoic acid, methyl ester (13.1\%), and 2- Cyclohexen 3,6, diol -1,one,2 tetradecenoyl(6.7\%). Biological activities of all these compounds are discussed in Table 1. Among all the compounds, it was found that only two compounds, Estra-1,3,5 (10)-trien 17 a-ol and 4H-1-Benzopyran 4-one,2-(3,4dimethoxy phenyl-7-hydroxy are reported to possess antimicrobial properties 4H-1-Benzopyran 4-one,2-(3,4-dimethoxy phenyl-7hydroxy, a homoisoflavonoid is a phenolic compound whereas Estra1,3,5(10)-trien $17 \mathrm{a}$-ol is steroid in nature $[47,48]$.

\section{CONCLUSION}

This study infers that Aspergillus sp. was the predominant endophytic fungi isolated from $C$. junghuhniana Miq. Qualitative phytochemical analysis revealed the presence of potential secondary metabolite of which predominantly were the presence of polyphenolic compounds, specifically SA and GA attributing for the antimicrobial activities in addition to the bioactive compounds analyzed using GC-MS. Further, the endophyte is also capable of producing enzymes such as lipase, cellulose, and amylase. Thus, the potential bioactive fungal endophyte can be effectively applied in the field of pharmaceutical and agricultural industries after standardization of various strain improvement traits.

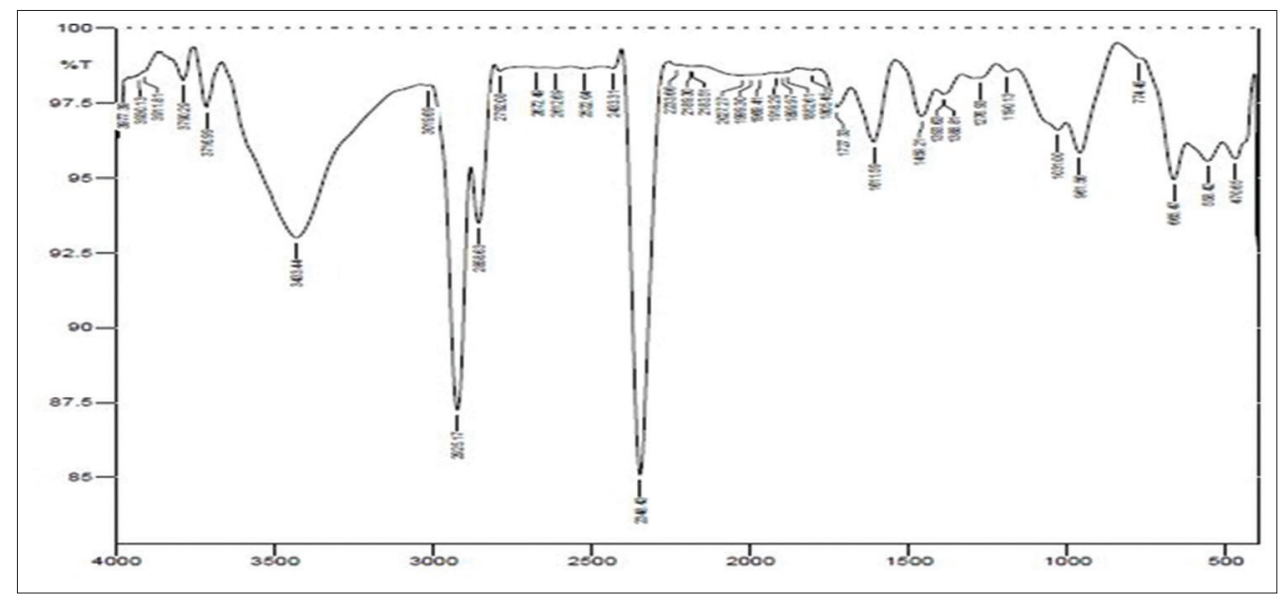

Fig. 4: Fourier transform infrared spectrum of Aspergillus sp. 


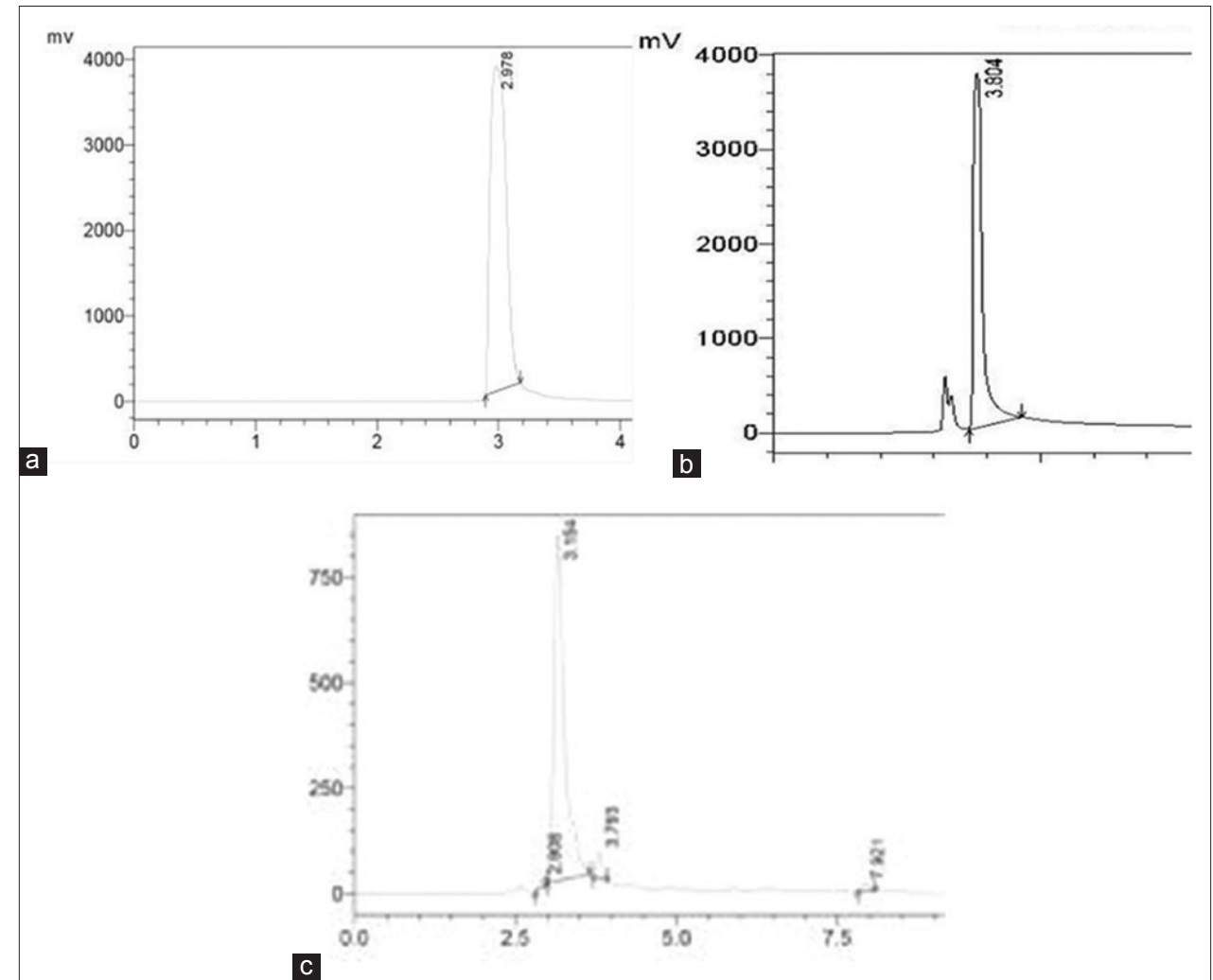

Fig. 5: High performance liquid chromatography (HPLC) analysis of standard. (a) Gallic acid, (b) Salicylic acid, (c) HPLC analysis of Aspergillus sp.

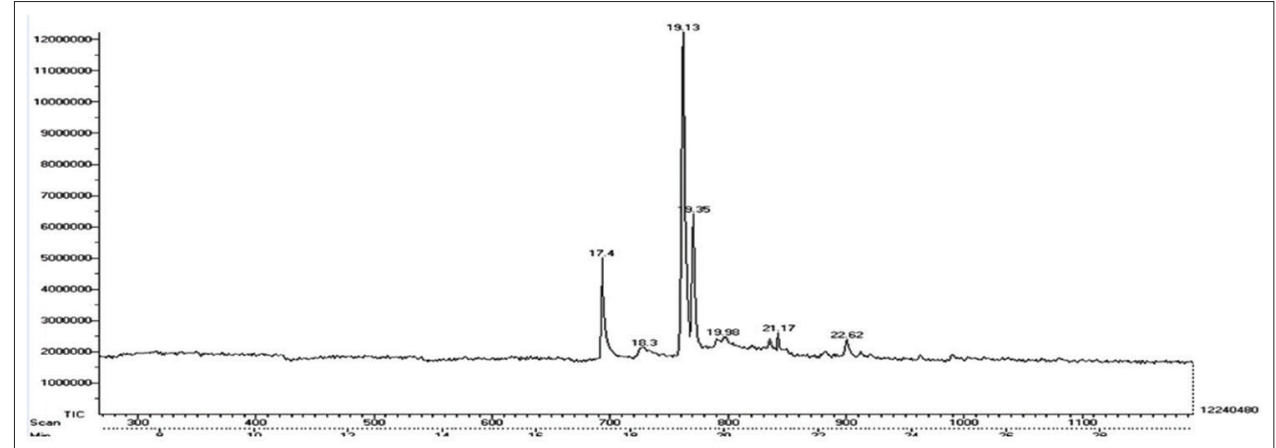

Fig. 6: Gas chromatography-mass spectrometry analysis of Aspergillus sp.

Table 1. Phytochemical compounds identified in ethyl acetate extract of Aspergillus sp.

\begin{tabular}{|c|c|c|c|c|c|c|}
\hline S. No. & $\begin{array}{l}\text { Retention } \\
\text { time (Rt) (minutes) }\end{array}$ & Compound name & $\begin{array}{l}\text { Molecular } \\
\text { formula }\end{array}$ & $\begin{array}{l}\text { Molecular } \\
\text { weight } \\
\text { (g/mol) }\end{array}$ & $\begin{array}{l}\text { Compound } \\
\text { nature }\end{array}$ & Biological activities \\
\hline 1 & 17.4 & 4,5,7-Trihydroxy isoflavone & C15H1005 & 270.24 & Isoflavones & Antioxidant, anthelmintic [49] \\
\hline 2 & 18.3 & Estra-1,3,5 (10)-trien 17 a-ol & C19H26O2 & 286.40 & Steroid & $\begin{array}{l}\text { Antioxidant, anti-inflammatory, } \\
\text { antifungal, antibacterial [48] }\end{array}$ \\
\hline 3 & 19.13 & Phytol & $\mathrm{C} 20 \mathrm{H} 400$ & 296.53 & $\begin{array}{l}\text { Acyclic } \\
\text { diterpene } \\
\text { alcohol }\end{array}$ & $\begin{array}{l}\text { Antidepressant, } \\
\text { anti- inflammatory } \\
\text { cytotoxicity [50] }\end{array}$ \\
\hline 4 & 19.35 & $\begin{array}{l}\text { 4H-1-Benzopyran 4-one, } \\
\text { 2-(3,4-dimethoxyphenyl-7-hydroxy }\end{array}$ & C21H14O2 & 298.33 & $\begin{array}{l}\text { Phenolic } \\
\text { group }\end{array}$ & $\begin{array}{l}\text { Nematicide, antifungal; } \\
\text { antibacterial [48] }\end{array}$ \\
\hline 5 & 19.98 & (E)-9-Octadecenoic acid ethyl ester & С20H3802 & 310.51 & Ethyl ester & $\begin{array}{l}\text { Nematicide, hepatoprotective, } \\
\text { antihistaminic, anticoronary [51] }\end{array}$ \\
\hline 6 & 21.17 & Eicosanoic acid, methyl ester & $\mathrm{C} 21 \mathrm{H} 42 \mathrm{O} 2$ & 326.55 & $\begin{array}{l}\text { Methyl } \\
\text { ester }\end{array}$ & Antioxidant [51] \\
\hline 7 & 22.62 & $\begin{array}{l}\text { 2-Cyclohexen 3,6, diol-1, one, } 2 \\
\text { tetradecenoyl }\end{array}$ & C39H80O2 & 580 & - & No activity reported \\
\hline
\end{tabular}




\section{ACKNOWLEDGMENTS}

The authors thank Mrs. Prema Sampathkumar, Associate Professor and Head, the Faculty members and nonteaching staff of Department of Plant Biology and Plant Biotechnology; Dr. Mrs A.Nirmala, Principal, Ethiraj College for Women, (autonomous) Chennai - 600 008, for their valuable support and encouragement throughout the entire period of research. We would also like to express our thanks for the facilities extended by the Central Instrumentation Centre of Ethiraj College for Women. Sincere thanks to IIT Madras for extension of facilities and State Forest Research Institute, Kolapakkam, Chennai, Tamil Nadu.

\section{REFERENCES}

1. Srivastava A, Anandrao RK. Antimicrobial potential of fungal endophytes isolated from leaves of Prosopis juliflora (SW.) DC, an important weed. Int J Pharm Pharm Sci 2015;7(12):128-36.

2. Xing YM, Chen J, Cui JL, Chen XM, Guo SX. Antimicrobial activity and biodiversity of endophytic fungi in Dendrobium devonianum and Dendrobium thyrsiflorum from Vietnam. Curr Microbiol 2011;62:1218-24

3. Teiten MH, Mack F, Debbab A, Aly AH, Dicato M, Proksch P, et al. Anticancer effect of altersolanol A, a metabolite produced by the endophytic fungus Stemphylium globuliferum, mediated by its proapoptotic and anti-invasive potential via the inhibition of NF-k B activity. Bioorg Med Chem 2013;21(13):3850-8.

4. Purwantini I, Wahyono, Mustofa, Asmah R. Isolation of endophytic fungi from $\mathrm{L}$. and identification of their antimicrobial compounds using bioaautography method. Int J Pharm Pharm Sci 2015;7(12):95-9.

5. Jose AC, Christy PH. Assessment of antimicrobial potential of the endophytic bacteria isolated from Rhizophora mucronata. Int J Curr Microbiol Appl Sci 2013;2(10):188-94.

6. Radu S, Kqueen CY. Preliminary screening of endophytic fungi from medicinal plants in Malaysia for antimicrobial and antitumor activity. Malays J Med Sci 2002;9(2):23-33

7. Zhao J, Shan T, Mou Y, Zhou L. Plant-derived bioactive compounds produced by endophytic fungi. Mini Rev Med Chem 2011;11(2):159-68.

8. Saikkonen K, Wäli P, Helander M, Faeth SH. Evolution of endophyteplant symbioses. Trends Plant Sci 2004;9(6):275-80.

9. Strobel G, Daisy B, Castillo U, Harper J. Natural products from endophytic microorganisms. J Nat Prod 2004;67(2):257-68.

10. Phongpaichit S, Nikom J, Rungjindamai N, Sakayaroj J, HutadilokTowatana N, Rukachaisirikul V, et al. Biological activities of extracts from endophytic fungi isolated from Garcinia plants. FEMS Immunol Med Microbiol 2007;51(3):517-25.

11. Dreyfuss MM, Chapela IH. Potential of fungi in the discovery of novel low-moleculae weight pharmaceuticals. In: Gullo VP, editor. The Discovery of Natural Products with Therapeutic Potential. London, UK: Butterworth-Heinemann; 1994. p. 49-80.

12. Schluz B, Boyle C, Draeger S, Rommert A, Krohn K. Endophytic fungi: A source of novel biologically active secondary metabolites. Mycol Res 2002;106(9):996-1004.

13. Thomas SN. Endophytic fungi in forest tree: Are they mutualists? Fungal Biol Rev 2007;21:75-89.

14. Al-Snafi AE. The Pharmacological importance and chemical constituents of Arctium Lappa. A review. IJPRS 2014;3(1-1):663-70.

15. Murugesan S, Sumathi R, Senthilkumar N, Rajeshkannan C, Karthikeyan A. Biotransformation of some secondary metabolite of Frankia-Casuarina relationship. Jayaraj RS, Warrier RR, Nicodemus A, Kumar, NK, editors. Advances in Casuarina Research in IndiaProceedings of the $2^{\text {nd }}$ National Seminar on Casuarinas; 2012. p. 271-6.

16. Jayaraj RS. Casuarina junghuhniana (Casuarinaceae) in India. Aust J Bot 2010;58(2):149-56.

17. Kannan CS Warrier EV, Anoop B, Singh G. Screening of clones of Casuarina equisetifolia for pulping traits using wood fibre characteristics. Int J Curr Res Rev 2015;7(12):12.

18. Fisher PJ, Petrini O, Sutton BC. A comparative study of fungal endophyte in leaves, xylem and bark of Eucalyptus in Australia and England. Sydowia 1993;45:338-54

19. Suryanarayan TS, Senthilarasu G, Muruganandam V. Endophytic fungi from Cuscuta rejlexa and its host plant. Fungal Divers 2000;4:117-23.

20. Domsch KH, Gamas W, Anderson TH. Compendium of Soil Fungi. New York: Academic Press; 1980. p. 168-9, 540, 559-60.

21. Raaman N. Phytochmeical Techniques. Ch. 5. New Delhi: New India Publishing Agency; 2006. p. 19-25.

22. Srinivasan K, Jagadish LK, Shenbhagaraman R, Muthumary J. Antioxidant activity of endophytic fungus Phyllosticta sp. Isolated from Guazuma tomentosa. J Phytol 2010;2(6):37-41.

23. Chang C, Yang M, Wen H, Chern J. Estimation of total flavonoid content in propolis by two complementary colorimetric methods. J Food Drug Anal 2002;10:178-82.

24. Senthilmurugan VG, Sekar R, Suresh K, Balamurugan S. Phytochemical sceening, enzyme and antibacterial activity analysis of endophytic fungi Botrytis sp isolated from Ficus benghalensis(L). Coden IJPRNK 2013;2(4):264-73.

25. Perez C, Pauli M, Bezevque P. An antibiotic assay by agar well diffusion method. Acta Biol Med Exp 1990;15:113-5

26. Boyle C, Gotz M, Dammann-Tugend U, Schulz B. Endophytehost interaction III. Local vs. Systemic colonization. Symbiosis 2001;31:259-281

27. Pandit S, Lawrence K, Singh A, Singh S, Lawrence R. Cellulase production by Aspergillus flavus and saccharification of wheat straw. Int J Sci Eng Res 2013;4(6):1965-71.

28. Hasan F, Shah AA, Hamed A. Industrial application of microbial lipases. Enzyme Microb Technol 2006;39(2):235-50.

29. Sharma R, Chisti Y, Banerjee UC. Production, purification, characterization, and applications of lipases. Biotechnol Adv 2001;19(8):627-62.

30. Jain P, Aggarwal V, Sharma A, Pundir RK. Screening of endophytic fungus Acremonium sp. For amylase production. J Agric Sci Technol 2012;8(4):1353-64.

31. Burhan A, Nisa U, Gokhan C, Ashabil A, Osmair G. Enzymatic properties of a novel thermostable thermophilic alkaline and chelator resistant amylase from analkaphilic Bacillus sp Isolate ANT-6. Process Biochem 2003;38:1397-403

32. Tran HB, McRae MJ, Lynch F, Brett CT, Waldron K, Unwin, Hyman, Palombo EA, editors. Identification and bioactive properties of endophytic fungi isolated from phyllodes of Acacia species. Current Research, Technology \& Education Tropics. Applied Microbiology and Microbial Biotechnology. Spain: Formatex; 2010

33. Muthukrishnan SD, Subramaniyan A. Phytochemical constituents of Gloriosa superb seed, tuber and leaves. RJPBCS 2012;3(3):111-7.

34. Jack IR, Okorosaye-Orubite K. Phytochemical analysis and antimicrobial activity of the extract of leaves of fleabane (Conyza sumatrensis). J Appl Sci Environ Manage 2008;12(4):63-8.

35. Segismundo $\mathrm{AB}$, Florendo $\mathrm{PE}$, Roman $\mathrm{PA}$. In vitro antifungal activity and phytochemicalscreening of Gouania javanica Miq. Leaves. UNP Res J 2008;17:1-10.

36. Stefanovic O, Radojevic I, Comic L, Vasic S. Antibacterial activity of naturally occurring compounds from selected plants. Antimicrobial Agents. Rijeka, Croatia: InTech; 2012.

37. Cowan MM. Plant products as antimicrobial agents. Clin Microbiol Rev 1999;12(4):564-82.

38. Wu T, He M, Zang X, Zhou Y, Qiu T, Pan S, et al. A structure-activity relationship study of flavonoids as inhibitors of $E$. coli by membrane interaction effect. Biochim Biophys Acta 2013;1828(11):2751-6.

39. Tsuchiya H, Sato M, Miyazaki T, Fujiwara S, Tanigaki S, Ohyama M, et al. Comparative study on the antibacterial activity of phytochemical flavanones against methicillin-resistant Staphylococcus aureus. J Ethnopharmacol 1996;50(1):27-34.

40. Alcaráz LE, Blanco SE, Puig ON, Tomás F, Ferretti FH. Antibacterial activity of flavonoids against methicillin-resistant Staphylococcus aureus strains. J Theor Biol 2000;205(2):231-40.

41. Liang H, Xing Y, Chen J, Zhang D, Guo S, Wang C. Antimicrobial activities of endophytic fungi isolated from Ophiopogon japonicus (Liliaceae). BMC Complement Altern Med 2012;12:238.

42. Borges A, Ferreira C, Saavedra MJ, Simoes M. The antibacterial activity and mode of action of ferulic and gallic acids against pathogenic bacteria. Microb Drug Resist 2013;19(4):256-65.

43. Coates J. In: Meyers RA, editor. Interpretation of Infrared Spectra, A Practical Approach in Encyclopedia of Analytical Chemistry. Chichester: John Wiley and Sons Ltd.; 2000. p. 10815-37.

44. Clarke JD, Volko SM, Ledford H, Ausubel FM, Dong X. Roles of salicylic acid, jasmonic acid, and ethylene in cpr-induced resistance in arabidopsis. Plant Cell 2000;12(11):2175-90.

45. Forchetti G, Masciarelli O, Izaguirre MJ, Alemano S, Alvarez D, Abdala G. Endophytic bacteria improve seedling growth of sunflower under water stress, produce salicylic acid, and inhibit growth of pathogenic fungi. Curr Microbiol 2010;61(6):485-93

46. Li S, Yu Y, Chen J, Guo B, Yang L, Ding W. Evaluation of the antibacterial effects and mechanism of action of protocatechualdehyde against Ralstonia solanacearum. Molecules 2016;21(6). pii:E754.

47. Das B, Thirupathi P, Ravikanth B, Aravind Kumar R, Sarma AV, 
Basha SJ. Isolation, synthesis, and bioactivity of homoisoflavonoids from Caesalpinia pulcherrima. Chem Pharm Bull (Tokyo) 2009;57(10):1139-41.

48. Ramesh R, Dhanaraj TS. Identification of bioactive compounds in the ethyl acetate extract of Terminalia arjuna root by GC-MS analysis. Int J Res Sci Res 48. 2016;7(3):9747-51.
49. Bouker KB, Hilakivi-Clarke L. Genistein: Does it prevent or promote breast cancer? Environ Health Perspect 2000;108(8):701-8.

50. Rajeswari G, Murugan M, Mohan VR. GC-MS analysis of bioactive components of Hugonia mystax L. (Linaceae). RJPBCS 2012;3(4):301.

51. Duke JA, Beckstrom-Sternberg SM. Dr. Duke's Phytochemical and Ethnobotanical Databases. Beltsville, Maryland: ARS/USDA; 1994. 